\title{
Voting on Sustainable Transport: Communication and Governance Challenges in Greater Manchester's ‘Congestion Charge’ Referendum
}

Dr Graeme Sherriff

Sustainable Housing and Urban Studies Unit

University of Salford

(revised version, following reviewer comments)

(Published $13^{\text {th }}$ May 2014 as: Sherriff, G. (2014). Voting on sustainable transport: communication and governance challenges in Greater Manchester's "congestion charge" referendum. Local Environment.

http://www.tandfonline.com/doi/abs/10.1080/13549839.2014.911267)

\begin{abstract}
In December 2008, the Greater Manchester electorate voted to reject a £3 billion package of transport measures that would have included investment in the conurbation's bus, tram and rail networks and walking and cycling infrastructure, together with, and partially funded by, the introduction of a congestion charge. The proposals followed a successful bid to the UK Government Transport Innovation Fund (TIF). High levels of car use present challenges to cities, and the TIF bid can be seen as an attempt to address these by promoting and facilitating modal shift. The paper reflects on the debates surrounding the proposals, which led to a referendum. In particular, it explores the challenges of communicating complex, controversial plans in a fragmented and contested political arena.
\end{abstract}

Keywords: Transport, Congestion Charging, Governance, Communication, Transportation Justice

\section{Introduction}

In December 2008, the Greater Manchester electorate voted to reject a £3 billion funding package that would have included wide-ranging investment in the conurbation's public transport network and walking and cycling infrastructure, together with, and partially funded by, congestion charging - in transport planning terms, combining carrot and stick to promote and facilitate modal shift. The vote followed a two-year period of debating and campaigning with much of the focus on congestion charging.

The task of this paper is neither to evaluate the decision to reject the proposals nor to assess their quality. It is to take the proposals as an example of an attempt to steer a city region towards a more sustainable transport future and to reflect on, and learn lessons from, the experience. In doing so, it contributes to literature on sustainable 
transport, the governance of sustainable transitions and the communication of public policy.

The challenge for the Association of Greater Manchester Authorities (AGMA) was not a technical one. The technology for road pricing has been demonstrated in other schemes. Neither was it, insofar as the scheme would have been funded by available national Government funds, an economic one. The major barrier to the implementation of the scheme was its public and political acceptability. The challenge for those in favour of the proposals was to overcome political differences within the conurbation's governance structure and to communicate to the public a set of complex and evidently controversial plans.

The structure of the paper reflects the relative weight of governance and communication in trying to meet this challenge. Following a methodological note on the author's involvement with the researched field, transport is presented as both challenge and opportunity. That is, whilst the environmental and social impacts of current transport patterns are cause for concern, the development of more sustainable systems offers opportunities to enhance quality of life, mitigate climate change and reduce social exclusion. The nature of the transport proposals is then outlined, with reference to how the proposed measures could have contributed towards the development of a more sustainable transport system for the conurbation. The subsequent section looks at the challenge of communicating the proposals to the Greater Manchester electorate, exploring in particular the ways in which the plans were simplified and at times misrepresented, and the ways in which the 'road user' was conceptualised. Section 6 explores the challenges presented by a relatively fragmented governance structure, deregulated and privately operated public transport, and prominent business interests, as well as by the decision to hold a referendum. Section 7 pulls together the discussion and presents some concluding observations.

Throughout the paper a distinction is made between TIF, the national Transport Innovation Fund, and GMTIF, AGMA's bid on behalf of Greater Manchester to the TIF fund.

\section{Methodological Note}

The paper builds upon several other studies on Greater Manchester's experience with TIF (see Royal Institute of Technology et al., 2011; Vigar et al., 2011; Swanson, 2009a). Given his personal involvement in the decision-making process, the author had access to a wide range of sources in addition to those normally available through a desk exercise. These include insider discussions, attendance of meetings of campaign groups and public debates, conversation with members of the public during campaigning activities, and access to ad hoc campaign materials, such as leaflets and posters, that are not available in public archives. The author was personally involved in the debate through a group that was part of the 'yes' campaign. This affords a level of 
familiarity with, and closeness to, the field that would be difficult to achieve using retrospective approaches but there is a risk that this is at the expense of impartiality.

It is intended that this close involvement helps to ground the research and that the fact that the paper argues neither for nor against the proposals themselves, and offers reflections and lessons rather than a post-mortem, reduces this risk. In any case, the "distinction between insider and outsider is not a simple one" (DeLyser, 2001, p. 442). Few could claim a completely disinterested stance on the future of transport, particularly in terms of costs to road users. Acceptance of approaches such as road charging has been a prominent strand in transport research. A recent open letter from 32 professors in transport-related fields, for example, raised concern that "our cities are simply not equipped to take further growth in road traffic" and argued for "a new way of charging for motoring as we move away from fossil-fuels" (Millward, 2013).

\section{Transport as Challenge and Opportunity}

There is broad consensus that high levels of car use are problematic and "that the ways in which and how much we travel are capable of causing appreciable harm to entire populations" (Docherty \& Shaw, 2008, p.3). This is reflected in policy: the recent EU White Paper (European Union, 2011) aims for 'conventionally-fuelled' cars to be phased out of city centres by 2050. Impacts include environmental damage, such as climate change, local air pollution and biodiversity loss; social issues including social exclusion (Lucas, 2004), loss of community (Rosen, 2001) and inactivity (Sloman, 2006); and economic impacts, including congestion and healthcare costs (Schiller et al., 2010).

Transport planning can go beyond minimising this negative impact and positively facilitate sustainability. Health can be enhanced through active travel (Frank et al., 2010) and social inclusion fostered by improving accessibility to services and social opportunities (Lucas, 2006). Walking and cycling routes can provide green lungs, and infrastructure can be built with green roofs and porous paving to contribute to climate change adaptation efforts (Gill et al., 2007).

It is argued that, as towns and cities have developed around car-based transport people have become increasingly car-dependent. As more people own cars, working, shopping and leisure patterns increasingly require them, thus exacerbating 'car dependency' (Newman, 2000). As motorised traffic grows, walking and cycling can become less attractive options (Sloman, 2006), public transport, potentially, becomes stuck in the same queues as the car and "the fragmented city becomes hostile and can even force reluctant users into their cars, thus exacerbating the problem" (Banister, 2005, p. 6). The dominance of cars seemingly enables the dispersal and speeding-up of common tasks such that "with the remaking of space around the car comes a restructuring of temporalities" and, as more journeys become difficult or impossible without private transport, the car can be seen to "create the conditions of its own necessity" (Watson, 2012, p. 492). It is these cumulative effects of car dependency that "warrant a coherent and focused intervention" (Hull, 2008, p. 96). 
Car dependency has associated justice and equity issues. In "car-dominant societies, lack of access to a car is in itself one of the key defining factors" in social exclusion, argues Lucas (2004, p. 294), since it becomes increasingly necessary to own a car to access essential services such as education, healthcare and employment. In some of the most deprived wards in Manchester, over $58 \%$ of households have no access to a car or van ${ }^{1}$. Although a limited proxy - since it does not reveal in how many households the vehicle is used by one person for work, leaving others reliant on lifts or other forms of transport - it illustrates the extent to which increasing car dependency can perpetuate social exclusion. There are those who are too old, too young, or otherwise unable to drive, and car dependency is experienced differentially, with some roles, such as a doctor making house calls, having higher mobility requirements than others, such as homeworkers (Martens et al., 2012). That is, it cannot be assumed that high per-household car ownership means that transport needs are being met. High levels of private mobility can contribute to social exclusion through environmental degradation, health impacts and community severance (Preston \& Rajé, 2007): those experiencing a lack of access opportunities also suffer the worst impacts of the transport system "they are both 'less travelled' and 'travelled-upon"' (Sustainable Development Commission, 2011, p. 8).

Whilst the notion of car dependency is compelling, it is important to note the aspects of car use that are not directly related to utility: it is "never simply about rational economic choices, but is as much about aesthetic, emotional and sensory responses to driving", argues Sheller (2004, p. 222). The "affective relations through which we inhabit cars and embed them into personal lives, familial networks and national cultures" (Sheller, 2004, p. 236) need to be understood. The pervasiveness of the car, it is argued, instils a cultural acceptance of its costs (Sloman, 2006, p. 34).

There are linkages between car dependency and the concept of lock-in (see for example Geels, 2012; Banister et al., 2011; Unruh, 2000). Unruh describes 'carbon lock-in' (Unruh, 2000) as the existence of a combination of systemic forces that perpetuate fossil-fuel-based infrastructure despite evidence of significant externalities and the existence of cost-effective remedies. This can be understood not only in terms of the economic dominance of the car industry, but also the persistence of 'behavioural trends'. The difficulty of changing travel habits has been conceptualised as 'dynamic lock-in' (Jackson, 2005, p. 121) and cultural factors, such as preferences for private property and for speed and time saving, combine to stabilise, i.e. reinforce, the dominance of the car (Geels, 2012).

\footnotetext{
${ }^{1}$ The 2011 UK Census results indicate that $44.5 \%$ of Greater Manchester households have 'no cars or vans in households', and that figures for the Ardwick, Moss Side and Harpurhey wards are $63.3 \%, 60.2 \%$ and $58.3 \%$ respectively. Available at www.neighbourhood.statistics.gov.uk.
} 
A range of measures are available to policy-makers. Santos et al. (2010) divide these into physical policies, such as developing infrastructure for public transport, walking and cycling, and integrating with land use planning; soft policies, such as car sharing and car clubs, eco-driving training and awareness-raising; and knowledge policies, such as incentivising research and development into, for example, the development of low-emissions and electric vehicles. Transport demand management, of which the GMTIF plans could be considered an example, focuses on finding the "right mix of incentives and/or disincentives that will encourage travellers to change their normal travel routine" (Meyer, 1999, p. 576). There is increasing recognition of the importance of lifestyles and behaviours (Schwanen et al., 2012; Anable et al., 2012), and the importance of understanding transport as a socio-technical system (Watson, 2012; Brand, 2005). Whilst technological changes are important, they are insufficient. This is not only due to the scale of the challenge (Watson, 2012) but also their limited reach: low-emissions cars neither decrease congestion (Kemp et al., 2012) nor encourage physical activity.

Arguably, UK transport policy has been disjointed, embracing climate change mitigation alongside the growth of motorised transport (Hull, 2008, p. 102). Whilst there are good examples of individual initiatives to promote alternatives, such as the six Cycling Demonstration Towns, which received funding for physical cycle infrastructure improvements and smarter-choices measures between 2005 and 2008 (Sloman et al., 2009), and the Local Sustainable Transport Fund, a fund launched in 2011 with the aims of facilitating local economic development and reducing carbon emissions through sustainable transport (Department for Transport, 2013), there is still a low take-up of active travel modes compared to many northern European countries. A recent research review noted that there have been some indications that the demand for domestic road transport in industrial countries may be levelling off, but concluded that this may not be a 'durable phenomenon' (Banister et al., 2011), and indicated that growth in passenger kilometres driven continues not only in the countries with rapidly growing economies, but also in countries with histories of investment in sustainable transport modes. Nevertheless, the automobility regime faces pressures in the form of niche innovations and contextual factors, such as climate change, peak oil and cultural changes (Geels et al., 2012; Rayner, 2011).

\section{Greater Manchester's TIF Bid as a Response}

\subsection{Introduction}

This section outlines the nature of GMTIF, the ways in which it was communicated and received in its early stages, and its potential to be a response to the challenges outlined above.

\subsection{The Proposals}


In July 2007 AGMA bid for money being offered from the UK Government's Transport Innovation Fund. AGMA is the local government association for Greater Manchester, with representation from each of the ten boroughs in the conurbation. The decision to go ahead with the bid followed a period of public engagement. Informal debate started earlier than this formal consultation, announced by the Manchester Evening News (M.E.N.) headline on $24^{\text {th }}$ January 2007 "Congestion Charging: It's coming our way" (M.E.N., 2007a). The TIF fund was aimed at local authorities and required a focus on demand management and anti-congestion packages, reflecting Government recognition of the London congestion charge combined with reluctance to commit to a national scheme (Dudley \& Chatterjee, 2012). In AGMA's bid - referred to here as GMTIF - $£ 1.5$ billion from TIF would be made up to around $£ 3$ billion by borrowing on revenue from a congestion charge over 30 years (Greater Manchester Future Transport, 2008).

\section{[Table 1 here]}

Although economic growth was emphasised in the rationale (Greater Manchester Future Transport, 2008), the proposals could also be viewed as a response to the challenges outlined above. By making driving more expensive at certain times, and investing in more sustainable modes, the plans had the potential to bring about modal shift by "produc[ing] a virtuous circle in shifting motorists to public transport" (Santos et al., 2010, p. 53) and to be an example of the established principles of transportation demand management (TDM) (Meyer, 1999). The charging element was the most prominent element of the package, and would be weekday peak-time only, in the direction of flow of peak-time traffic, chargeable on driving past either or both of two cordons. Depending on when and how many cordons were passed, the charge would be between $£ 1$ and $£ 5$ over a day (see schematic, Figure 1).

The plans followed the earlier introduction of the most high-profile congestion charging system in Britain. London introduced charging in 2003 alongside significant improvements in an already well-regarded public transport system (Givoni, 2012). It was implemented by Mayor Ken Livingstone and represented a "highly visible, very deliberate, very political effort to reduce car use and congestion in the capital" (Shove \& Walker, 2010, p. 473).

Alongside the 'stick' of the congestion charge, GMTIF included 'carrots' to facilitate and incentivise modal shift. Such changes offer "windows of opportunity in which travel habits (e.g. driving) are disrupted and must be renegotiated" (Whitmarsh, 2012, p. 3). These included extensions to the Metrolink tram network, an expanded cycle lane network, additional yellow school buses, new train carriages, improved interchange facilities and better integration of the bus network. Such investment creates opportunities for currently car-dependent commuters to take other options. For example, new school bus services may reduce the need for parents to drive or walk their children to school and therefore enable them to take public transport to work. 
The plans included better integration and smart ticketing and these, combined with an increase in the number and frequency of services, were intended to help make public transport a more attractive proposition and move towards a stronger, more integrated public transport offer. With the currently privatised, multi-operator system of buses, trams and trains, the area can appear to have a collection of services rather than a network, a situation commonly found in England and Wales outside of London (Sorensen \& Gudmundsson, 2010).

The plans also included personalised journey planning and promotional activities. These 'soft measures', understood as initiatives that aim to bring about behavioural change through information about consequences and alternatives (Santos et al., 2010, p. 48), were intended to act alongside the infrastructure improvements and help commuters explore options, thereby helping to tackle some of the behavioural aspects of car dependency, such as lack of experience of public transport and confidence in cycling.

\subsection{Reactions to the Proposals}

Although in the initial stages there were no plans for a referendum, 'pro' and 'anti' camps formed, and these could be mapped onto the subsequent 'yes' and 'no' positions of the referendum. An early presence in the 'pro' campaign was Clean Air Now, a coalition led by environmental campaigners and later joined by the official 'yes' campaign and United City, a coalition of businesses. The 'anti' campaign was initiated by campaign group Manchester Against Road Tolls (MART), backed by the national Association of British Drivers (ABD), and later joined by a coalition of businesses, the Greater Manchester Momentum Group (GMMG) (Forster, 2008). Shark and squirrel characters became mascots for the 'no' and 'yes' campaigns respectively, with the shark attending consultation roadshows and appearing in viral videos taking money from people as they tried to buy a beer or go on holiday (figure 2) and the squirrel responding with the motto "Say no to £3billion? You must be nuts!" (figure 3). The arenas for campaigning included the local press, with some newspapers taking particular campaigning stances; local radio and television; various organised public meetings; the tables of the area's pubs, on beer mats; and billboards around the conurbation.

Once national Government had accepted the bid in June 2008, subject to public approval, there was a period of further debate and a formal consultation on the proposals. Campaigning for and against had been continuing and there were calls for a referendum, particularly from opponents (M.E.N., 2007b). In July 2008, AGMA announced that there would be a referendum in December of that year. The results were announced on $12^{\text {th }}$ December $2008: 78.8 \%$ against and $21.2 \%$ for, with an overall voter turnout of $53.2 \%$ (Ottewell, 2008a). The proposals were therefore not implemented.

\section{A Communications Challenge}


This section explores the challenge of communicating GMTIF to politicians, other decision-makers and, ultimately, the electorate. It starts by looking at the nature of the messages and then comments on the evident focus on the congestion charge element of the plans, the misrepresentation of information, the simplification of the plans, and comparisons with the London system. It then discusses the ways in which road users were framed and conceptualised in the debate and the implications of this framing.

\subsection{Simplification of the Proposals}

Overall, the project was "characterised by a complicated message" (Swanson, 2009a, p. 4), and transport planning is already a complex field. In many ways the complexity of the GMTIF scheme reflects an attempt to overcome some of the criticisms commonly made of road charging, as Vigar et al. agree (2011). By using a loan to enable public transport improvements before introducing charging, there was potential to overcome a common 'chicken and egg' dilemma: public transport improvements being needed before charging, yet the money from charging being needed to fund them. The planned charging regime was also less 'blunt' than, for example, the London charge, with the charge only being incurred when crossing one of the two cordons, only at certain times, and only in the direction of peak-time traffic. Whilst this level of sophistication arguably made the scheme more precisely targeted at congestion, and therefore in some senses easier to 'sell', it added a level of complexity in communicating it, and therefore of gaining public and political understanding and support.

Observations of the media coverage and campaign messages suggest that there was a degree of simplification. Vigar et al., in their survey of media in the run-up to the vote, agree that "it is apparent that many dimensions of GMTIF were under explained" (2011, p. 478). Concerns over the clarity of communication have led some to question the extent to which people fully understood the plans and, in particular, the longer-term implications (Dudley \& Chatterjee, 2012). "Very few people", recalled Roy Newton of the Joint Transportation Policy Team, "got the message that a significant investment in public transport was the major component, and even fewer people knew that public transport investments would have to be fully implemented before the congestion charge would begin" (interviewed in Swanson, 2009b, p. 25).

There were several aspects to this simplification. Firstly, there was a particular focus on the congestion charge element of the proposals - unsurprisingly, as this was perceived to be the most controversial element - with the process repeatedly referred to with variations on 'congestion charge referendum'. Reference to the public transport was generally included in newspaper articles but often further into the article. Vigar et al. agree, also finding that the improvements were often presented as a 'sweetener', with the congestion charge as a 'bribe' (Vigar et al., 2011, p. 478). This framing was common from early in the process, an example being "The government is offering 
Greater Manchester up to £3bn for public transport improvements in return for the peak hour only charge of up to $£ 10$ [sic]" (M.E.N., 2007c).

Secondly, there were examples of misrepresentation of information, whether wilful or not. One example is the M.E.N. front page in March 2007 "Congestion Charge, you say NO" on which it was reported that "two out of three reject plans to bring in pay-as-youdrive" and "but 59 per cent of you back move - if it brings cash for Metrolink" (M.E.N., 2007c). The plans did include funding for Metrolink, so the headline would more accurately have read 'you say YES'. Whether intentional or not, such reporting would not have helped the public to clearly understand the proposals.

Some media organisations openly ran campaigns. The Advertiser for North and East Manchester, for example, featured cut-out 'NO' coupons on its front pages and simplistic headlines such as "Toll Tax to Cost £1,000 Per Year" (Thompson, 2007). One example framed the proposals with: "Sir Richard Leese, deputy leader of AGMA, denied that congestion charging was a stealth tax on the ordinary people of north and east Manchester to help pay for the Metrolink" (Thompson, 2007). In one issue it ran a debate, with a column for both sides of the argument and a cut-out coupon at the base of the page with 'NO' as the only option (The Advertiser, 2007).

This is not to argue that the media consistently misrepresented information or was always against GMTIF. The M.E.N. in particular published some statements in favour. One example is an article featuring then Manchester United manager Alex Ferguson arguing that the proposals were an opportunity to put Manchester in the "premier league of public transport" (Ottewell, 2008b). Rather, it is to highlight the charged and potentially confusing way in which the details of the GMTIF were communicated to the public.

Thirdly, the plans themselves were routinely simplified, particularly the financial aspects. The complexity of the charging system created opportunities for simplification. Advertising on billboards, beer mats and viral videos repeated annual and daily figures, typically $£ 5$ per day and $£ 1,200$ per year: in each case this was the maximum charge. In February 2008, the Advertising Standards Agency upheld a complaint concerning MART adverts with the slogans "Stop Moaning. What's $£ 5$ a day?" and " $£ 5$ a day won’t even buy me a cigar": "Because [the adverts] did not make clear that $£ 5$ a day was the current maximum proposed charge under the scheme we concluded that the ads could mislead" (Advertising Standards Agency, 2008).

A later beer mat ran with the slogan "Don't let $£ 1,200$ a year mean last orders for your pint!" (figure 9), qualifying it slightly on the rear "It could cost you up to $£ 100$ every month... just to drive to work". This is an example where presenting a simplified 'anti' argument was easier and more powerful than the counter-argument, which would have entailed describing the detail of the time- and direction-contingent charging regime. The official 'yes' campaign circulated leaflets in the run-up to the referendum and these 
included information on the public transport improvements, but the core messaging of these and the billboard adverts that accompanied them was "9 out of 10 people won't [be required to] pay - will you?" - apparently countering the "hitting your pocket' focus of the opponents by appealing to those who would not, given their travel patterns or personal situations, pay the charge.

Fourthly, comparisons with the London system belied the comparative complexity of GMTIF. The GMMG beer mat (figure 9) states that it would "create the world's largest congestion charging zone - the area within the M60 motorway - that's 80 sq miles compared to the original London zone of 8sq miles" - yet the schemes were quite different with London's based on a zone and Manchester's around two cordons. A spokesperson for the Greater Manchester Momentum Group repeated this claim in Local Transport Today shortly before the vote (Forster, 2008). Opposition campaigners in the debate leading to Edinburgh's referendum contended that the addition of a second cordon in their scheme added to the complexity and reduced public understanding to the extent that they believe that "they could have won with a simpler scheme" (quoted in Rye et al., 2008, p. 648).

\subsection{Constructing 'The Driver'}

Also of interest in seeking to understand how the plans were communicated is the framing of road users. Given the focus of the media on the congestion charge element of the plans, 'the driver' seemed to take centre stage in media coverage, implying a simplified conceptualisation of mobility.

Headlines and claims like "Drivers to Pay $£ 1,200$ " a year were simplifications of the proposals and belied the potential for public transport investment to create feasible alternatives for many 'drivers'. One of the first headlines in the M.E.N., for example, was "Is THIS really an option for drivers?" with a photo of a crowded tram; implying not only that being a 'driver' is an identity, rather than a performance of the practice of driving, but also that public transport was in some way not good enough for them. However, as King et al. (2007, p. 113) argue, although the charging is likely to "harm most drivers, no one is only a driver" - a 'driver', or their family, could benefit from being able to use a new tram route, or benefit as a parent or resident from lower traffic levels.

Some proponents did question this. After the M.E.N. launched a survey to let 'drivers' report problems with congestion, Manchester Friends of the Earth, the Community Network for Manchester and the Environment Network for Manchester signed a letter to them arguing that "No one is simply a 'motorist' - we all have a range of transport modes available to use, depending on the journey we are making" (Clean Air Now, 2007). 
An implication of high car dependency is that car use becomes associated with basic freedoms, with appeals to the 'freedom of the motorist' for example (Cahill, 2007, p. 91). A striking example was found in the M.E.N., which, under the headline "Berlin Wall for Manchester", with no reference to the public transport investment or the time-limited nature of the charge, quoted MART: "Congestion charging will create an electronic Berlin Wall around Manchester and the M60 will become a barrier that will keep people in and money out" (Kirby, 2007, p. 17). The charging system would not restrict the flow of people using public transport or cycling, as the Berlin Wall did, yet the article entertained the idea that basic freedoms were being threatened. In a related protest, hearses "represent[ed] the death of Manchester business and freedom" (M.E.N., 2007d). This is an example of a campaign group playing on a latent sense of injustice stemming from the basic freedoms associated with car use.

Constructing and perpetuating this identity of 'driver' can be seen to be problematic, considering that a core principle of sustainable transport is a shift from emphasising one mode ('uni-modality') to embracing plurality ('multi-modality') (Schiller et al., 2010, p. 3), such that the mode of transport is determined by the demands of a particular journey rather than habitual use. One is neither a 'driver', a 'motorist' nor a 'cyclist', but someone who needs to get from A to B. Yet these 'identities' have become embedded in identities and cultures:

"Reducing car-dependence is not just a case of providing better public transport and cycling facilities, improving cycling infrastructure... It also requires the much harder job of unpicking the ways in which cars... form part of the identities of individuals, organisations and indeed the wider culture." (Skinner \& Rosen, 2007, p. 95)

For both 'sides' of the debate this close association between mobility and freedom translated into claims to social justice, albeit differently framed. The justice claims of the opponents can be understood to stem from an emphasis on mobility and a close association between this and private car use. The potential for the charge to affect poorer drivers the most was highlighted, with the implication that the roads would, in effect, be 'free for the rich' (figure 4) and the poor would not be able to access work without resorting to the other modes of transport, such as the bicycle (figure 5).

Conversely, the proponents tended to present non-car modes positively. Clean Air Now (CAN)'s 'Tour de TIF' (Clean Air Now, 2008) cycle ride highlighted the opportunity to promote cycling as a healthy and sustainable mode. Leaflets produced by CAN suggested a 'yes' was an early Christmas present (figure 6), and highlighted the extent of the public transport investment (figure 7). They argued that it would be the poorest in society, who do not have cars, who would benefit the most from the investment. They also tended to make reference to environmental issues such as air pollution and climate change, and argued that the quality or reliability of journeys would improve (figure 8). 
The 'yes' and 'no' approaches represent alternative approaches to addressing social exclusion related to car dependency, as outlined in Section 3. The 'no' campaigners argued that making car travel more expensive exacerbates social exclusion, whereas the 'yes' proponents argued that, by investing in alternatives and reducing the growth of car use, policy can seek to be more inclusive. It is important to recognise these strongly felt notions of justice and not to underestimate their role in shaping opinion. Part of the challenge for those proposing such schemes is to communicate a more complex, holistic conceptualisation of justice that recognises a role for charging as long as it is balanced with effective investment in alternatives.

\subsection{Discussion}

This discussion has been premised on the assumption that the media have a significant effect on opinions and attitudes (Ryley \& Gjersoe, 2006). "In our mediamediated world", argue Brand and Fischer (2012, p. 13), "small chunks of information sell... information for the masses has to be made accessible and straightforward, which pushes towards a simplified picture of a complex scenario." Vigar et al. found that in general "the press resorts to a narrow repertoire of words and metaphors to define transport issues" (Vigar et al., 2011, p. 478) and identified a need to better understand how these are interpreted by the public. Manchester's GMTIF debate can be seen to be an example of this. In developing his co-evolution thesis, Brand (2005, p. 67) argues that the question that is asked, and by extension the way the question is framed, can delimit the perception-space of answers, such that "limits to describe are limits to imagine" (Brand, 2005, p. 67). It could be argued, then, that a certain poverty of vocabulary was evident in the press coverage and, to the extent that such coverage helped to promote and shape debate, such poverty may have translated into a poverty of argument and vision.

\section{A Governance Challenge}

This section looks at GMTIF in the context of Greater Manchester's governance. It discusses aspects of the governance structures, political divides and business interests that presented particular challenges to the decision-making process. The operational governance of public transport is also of interest. Finally, some observations are made about the ways in which deciding to hold a referendum on the issue added to the challenge.

\subsection{Context}

GMTIF was born into a fragmented governance setting. The ten local authorities in AGMA were a combination of Labour, Liberal Democrat and Conservative and AGMA sought agreement between these parties in order to progress the plans. For this purpose, AGMA amended its normal consensus vote to a majority vote (Ottewell, 
2007a) and decided, with a majority of eight, to bid for TIF funding. Central

Government's decision to award the conurbation the funding was influenced by AGMA being able to demonstrate broad support for the proposals, evidenced by an early consultation exercise ${ }^{2}$ (Ottewell, 2007b). Nevertheless, the months that followed were characterised by further political debates. At the time of the referendum three councils were opposed: Stockport, Trafford and Bury (Forster, 2008). Stockport Borough Council was vocal in its opposition (Stockport Express, 2008). In the period running up to the vote it attempted to arrange bus advertising to oppose the plans (BBC, 2008a).

It cannot be known how this process might have turned out under different circumstances, but it is clear that aspects of Greater Manchester's governance undermined efforts to forge a decision to go ahead. "If the public gives the proposals the 'thumbs up'," argued Forster, "then victory will have been achieved in spite of, rather than because of, the conurbation's local governance structure" $(2008$, p. 30). The tendency of governments to reinforce the status quo rather than enable radical change is a factor in the development of transport systems. Pierson argues that the idea of path dependency is as relevant to politics as economics: "it is frequently more difficult to reverse course in politics than it would be in economics" (Pierson, 2000, p. 260). As the dominance of the automobility regime (Geels et al., 2012) becomes stronger and more entrenched, the political cost of change becomes greater.

The decision to hold a referendum, which followed campaigning, primarily by opponents, appears to have been in part a result of the failure for the ten boroughs to reach agreement. Sir Richard Leese, Manchester City Council leader, had not been in favour of a referendum, arguing that it "would not work" for such a complex issue and preferred the decision to be made through the "system based on elected representatives who have to take difficult and important decisions" (Ottewell, 2010). Some felt that the decision to hold the referendum was an "admission of failure" (Harding quoted in Swanson, 2009b, p. 24) or buck passing. Similarly, in the Edinburgh case, it was argued that the referendum was a "politically expedient way to distance the then ruling Labour group from making a decision on the congestion charging scheme" (Rye et al., 2008, p. 654). Whilst the Greater Manchester authorities may be criticised for lacking decisiveness in pursuing the programme, some politicians felt that the buck had already been passed from central Government (Swanson, 2009b), which did not have the boldness to push congestion charging directly but had instead made it an essential component of bids to TIF.

\subsection{Leadership}

\footnotetext{
${ }^{2} 57 \%$ of residents surveyed agreed with the principle of paying charges in return for the package of public transport investment. $68 \%$ agreed that a bid should be submitted to TIF, but that no decision should be made on the charging scheme until more details were available.
} 
The proposals lacked a high-profile, top-level figure to champion them, in contrast to London, where Ken Livingstone personally championed the congestion charging plans, and it was he, rather than national Government, who took the political risk (Dudley \& Chatterjee, 2012). The Greater Manchester Passenger Transport Authority (GMPTA) and AGMA were expected to maintain a neutral stance, co-ordinating the consultation and disseminating neutral information about the plans. In such a charged political climate, they could not be seen to be taking sides. Shortly before the vote, a $£ 230,000$ TV advert was pulled from broadcast over concerns that its presentation of the facts could be biased, despite it being cleared by independent broadcasting body Clearcast (Ottewell, 2008c).

Councillor Roger Jones, arguably the public figure most closely associated with GMTIF in 2008, lost his seat in the 2008 local elections and subsequently stepped down as chair of GMPTA. Having publicly supported the plans, this was seen by some in the media as something that should "send a message to his colleagues and potential successors" (Ottewell, 2008d) and, by MART, as confirmation that "the congestion charge is a cast-iron vote loser" (quoted in Ottewell, 2008d). Even in June 2011, on reelection, the local press referred to him as "Congestion Charge Mastermind" (Kirby \& Welsh, 2011) and referred to him being "ousted", illustrating the longevity of the reputational risk of supporting a controversial scheme. In fact, this legacy affected the Manchester Labour Party as a whole: when the Greater Manchester Combined Authority was created in 2010, it was decided that all issues would be decided on a simple majority, except for road pricing, which would require unanimity (Hayman, 2010). A local councillor commented that "this is a very good safeguard against Labour leaders and nonelected civil servants within some councils trying to force a congestion charge upon Greater Manchester"' (The Bolton News, 2010).

\subsection{Business Involvement}

It is also important to shed light upon the interface between business and government. A group of prominent businesses in the area established the Greater Manchester Momentum Group (GMMG) to campaign for a 'no' vote. In 2008, Peel Holdings was allegedly carrying out voter research in the constituencies of politicians related to transport, such as Councillor Roger Jones and Transport Secretary Ruth Kelly, asking voters if they supported congestion charging (Binns, 2008) and, reportedly in one case, if they were aware of the position of Councillor Jones on this issue (M.E.N., 2008). Another local company, Kellogg's, was criticised for emailing its employees with a 'cut and paste' section of text with which to respond to the official consultation and reflect their employer's stance against the proposals (BBC, 2008b). Whilst businesses clearly have a legitimate voice on policy in a city region, this example highlights the sometimes opaque nature of their interventions and the need for a good understanding of the 'behind the scenes' influences on policy and decision-making processes. Whilst business often has a privileged position in policy-making, as "government relies greatly 
upon business to carry out basic functions such as employing people and organising the economy" (Dryzek, 1997, p. 99), its views are not necessarily unbiased or representative, and powerful interests with financial resources may "skew the outcomes of policy debates" (Dryzek, 1997, p. 98), either directly, as stakeholders, or indirectly by influencing the electorate.

\subsection{Public Transport Governance}

Another aspect of governance is the operation of public transport. The deregulated, privatised public transport system added further complexity to the governance of transport operations - and this had specific implications for GMTIF. The transport authority did not have control over fares and service standards, contributing to a lack of trust that GMTIF could deliver the revolution in transport that was being promised. Furthermore, campaigners were able to claim that much of the GMTIF money would be spent on improving the services of private bus and train operators and that they should be investing in improvements in any case. Whilst the Local Transport Act had opened up possibilities for the authorities to take back some control over the bus companies, and GMTIF funding would offer opportunities to pay for integrated ticketing, this complexity was absent from most public debate. The frame of reference for the public was the current expensive, disjointed and, in places, infrequent public transport system. In comparison with London, Manchester's starting point for congestion charging was quite different. The capital had enjoyed a "highly developed public transport system, and the systems and structures of governance to manage and invest in it" and "a much more balanced pattern of mobility than anywhere else in the UK" (Docherty \& Shaw, 2012, p. 118). One member of the Manchester public interviewed by Local Transport Today in the run-up to the referendum reflected this lack of faith in the ability of the authorities to deliver on their promises, and the extent to which poor levels of service can become locked in by a lack of faith in the authorities to do better:

And isn't he tempted by the promise of better public transport? 'It's always late, never turns up when it should do. You might as well drive 'cos at least you know you'll be on time for work" (Local Transport Today, 2008, p. 1).

\subsection{The Referendum}

The experience of the referendum illustrates the difficulty of translating a strategic longterm macro-level decision into a collection of individual short(er)-term decisions, and the difficulty of these decisions forming a collective whole. It calls into question not only the suitability of a referendum process, but also the ability of the democratic system to bring about radical change, or, in lock-in terminology, a discontinuity. The binary choice, and outcome, of the referendum arguably became a simplified representation of a complex issue and did not facilitate deliberation of the finer details, advantages and 
disadvantages, nor was voting able to communicate anything more than a 'signal' (Warren, 2012, p. 14). This led to what could be termed unexpected voter behaviour, such as regular cyclists voting against the plans, because they believed the investment in cycling infrastructure to be insufficient, even though they agreed with the overall principles.

The following two quotations illustrate the difficulty of reducing such a complex decision to a binary vote. Vicky and Gemma, interviewed waiting for the bus, were pessimistic about the plans:

"People think that because you're paying the congestion charge it's going to reduce cars on the road but I don't think it will... there'll be the same congestion problems." (Local Transport Today, 2008, p. 1)

Mr and Mrs Tudge are visiting the Asda superstore near their house:

"To come from where we live now to here we'd have to pay the congestion charge. We've just got to cross the bloody road here half a mile, and we've got to pay a congestion charge to come to Asda!" (Local Transport Today, 2008, p. 7)

The former are voting against because they believe it will not work effectively, and, as bus users, could be assumed to benefit from it, whereas the latter are voting against because they believe it will work too well and would interfere with their car use. The latter is an example of the dilemma that Monbiot presents, that the decarbonisation agenda "is a campaign not for abundance but for austerity... It is a campaign not for more freedom but for less" (Monbiot, 2007, p. 215). This also applies to decisionmakers, with "politicians seeking re-election" finding it "very difficult to tell their electorate that it needs to change behaviour in ways that might be perceived as lowering [their] quality of life" (Brand \& Fischer, 2012, p. 12).

There was also an issue with familiarity with the subject matter. As Pierson (2000, p. 260) argues, many participants in politics engage in activities only sporadically. He points to research that indicates that actors who operate in contexts of high complexity and opacity tend to filter information into existing 'mental maps'. This is pertinent to GMTIF since the majority of the voters will not have engaged in transport planning prior to the referendum and will have had only a short amount of time to digest the plans and get to grips with the complex set of issues surrounding transport in Greater Manchester. Whilst doing this they will have been bombarded by campaign messages 
and media content which, as has been seen, did not do justice to this complexity. This would also apply to elected members outside of the transport and related committees.

An example of this is the public's lack of familiarity with local government finances. One of the concerns raised by commentators, and emphasised by the 'no' campaign, was the amount of money involved, approximately £3 billion, and the fact that half of this was a loan, and therefore a risk. At the same time, Greater Manchester Waste Disposal Authority (GMWDA), serving nine of the ten AGMA boroughs, had signed a deal for waste services over 25 years with the value of $£ 3.8$ billion, including a mixture of grant funding and finance (GMWDA, 2009). Whilst to voters unfamiliar with local government finance a $£ 3$ billion package might seem a huge risk, the GMWDA example shows that such long-term, high-value packages are not alien to local government. Even if such claims were scaremongering by 'no' campaigners, it is important to question the extent to which the public had the necessary information to counter such claims.

\subsection{Discussion}

These observations present a picture that is a long way from notions of the wellinformed electorate and communicative rationality (see Campbell \& Marshall, 2002), and highlight the need to recognise power and knowledge disparities, strategic behaviour and deception (Hay, 2002, p. 315). They also highlight the ways in which governance structures can contribute to inertia in decision-making and the limitations of a referendum process in representing opinion on a complex issue.

\section{Conclusions}

GMTIF was an opportunity to address some of the challenges of transport planning in cities. In particular, it sought to use 'carrot' and 'stick' approaches along with infrastructure improvements and information approaches to promote modal shift. It failed to win political consensus or electoral support. Although some of the elements of it have now been implemented, for example extensions to Metrolink, they have not been part of a wider package and have not included 'stick' measures, such as congestion charging. This section summarises five key lessons from this attempt at a conurbation-wide step change in transport planning and ends with some concluding remarks.

Firstly, the experience of seeking public support for GMTIF highlighted the controversial nature of plans to increase the cost of driving, and, as discussed, these are related in part to the way that private mobility is associated with freedom and social justice. Campaigns against the proposals were commonly framed in terms of the potential exclusionary impact of increased costs, whereas campaigners in favour emphasised other justice issues, including the potential for those on lower incomes to benefit from public transport, the impacts of heavy traffic on such groups, and the wider justice implications of climate change. These examples highlight the contested nature 
of transport justice and the challenge of communicating complex conceptualisations of justice in which congestion charging, coupled with public transport investment, can be viewed more positively.

It could of course be argued that these claims to justice were actually distortions by powerful business and political interests, and it certainly appeared that claims were focused upon, even amplified, in campaigns. However, the strength of feeling about the social justice elements of the plans, not only from campaigns, but also members of the public at public meetings, stations and tram stops, suggests a genuine concern. As Dudley and Chatterjee argue: "suspicions about the non-transport implications, such as the consequences for privacy and social justice, are easy to exploit in a context of uncertainty" (2012, p. 98). Accepting that such concerns can be 'exploited' by campaigners (on both sides) does not discount their importance. If anything, it emphasises the importance of engaging with these issues and ensuring transport policies are, and are understood to be, progressive.

Secondly, whilst the complexity of the plans reflected in part an attempt to make them more precisely targeted at congestion, this made communicating them in a fragmented and contested political arena more challenging. It presented an unenviable communications challenge to the proponents of GMTIF in proposing a complex scheme, impacting on an extremely sensitive area of residents' lives at a time of economic downturn.

Thirdly, it is unsurprising that the public debate and media coverage surrounding the referendum became focused on the congestion charge. The examples above illustrate this focus and also suggest that media coverage could be seen to be selective and at times, whether intentionally or not, misleading.

They bring into question assumptions about an informed electorate and remind us that transport planners and other relevant decision-makers were not able to set the terms of the debate and this limited their ability to communicate the wider benefits of the proposals. There is a need to better understand the 'interpretative repertoire' (Vigar et al., 2011, p. 478) that the public and decision-makers are using and to explore how to enrich the vocabulary of the media in talking about transport.

Fourthly, the referendum process is extremely limited in facilitating decision-making that does justice to the complex and controversial nature of the plans. The difficulty of distilling such a complex decision into a binary choice by an electorate who could not be expected to become transport planning experts in such a short space of time, and did not necessarily receive clearly balanced information, suggests that other means of effective involvement need to be developed.

Fifthly, there are clear governance and social dimensions of lock-in: demonstrating that even if a project is economically and technically possible, systemic barriers can arise 
from government and society. Additionally, local issues, from specific governance arrangements to the performance and reputation of public transport, are factors in perpetuating the status quo.

By way of a concluding observation, this discussion highlights for the author the importance of rethinking the way that the purpose of transport planning is conceptualised and the ways in which perceptions and framings can limit the capacity for radical change. Ferreira et al. (2012) argue that placing emphasis on increasing mobility is like measuring the success of a gold mine by how much land is moved, rather than how much gold is obtained. Their point is that too often the focus is on the extent to which people are moving around, rather than the impact, positively or negatively, of that movement. They argue that accessibility is the goal (or gold) of transport planning and question the logic of increasing the extent that people move around unless this has positive implications for accessibility. Accessibility can, for example, be achieved by locating services close to where people are - more gold, less land moved, to continue Ferreira et al.'s metaphor. Following the opening exploration of literature and policy in section 3 , health and environmental sustainability might be added to the goals of transport planning to construct 'sustainable accessibility'.

Increasing mobility is only a subset of the options available to policy-makers in promoting sustainable accessibility, and in some cases can be counterproductive: for example, if the result is that people have to drive, or take a bus, further to access groceries. In turn, car-based mobility is a subset of the options available for increasing mobility: walking, cycling and public transport are often preferable in environmental, social inclusion and health terms.

In this conceptualisation, in which mobility is one way of achieving these wider social goals, and car-based mobility just one form of mobility amongst many, the 'motorist', insofar as such an identity exists, is shifted from centre stage to be just one actor in a transport system. This conceptualisation resonates with debates in transport planning and research, but was largely absent from the public debates on the proposals, which instead became focused, on both 'sides', on how much individuals would be paying to drive, as if keeping this low was the only goal of transport planning. This results in a narrow focus, obscuring the bigger picture. As Wolmar argues, 'simplistic arguments about taxation and fleecing the motorist make it impossible to develop and implement rational long-term policies that would benefit wider society' (Wolmar, 2008).

It is difficult to imagine a leap from the simplified debates on AGMA's proposals to this more nuanced understanding, but an emphasis on a sense of justice that places automobility at centre stage, rather than at the edge, is a factor that can be seen to lock us in, conceptually, to transport systems centred around the car. Whilst those individuals who opposed the plans can celebrate, the need to tackle the wider societal problems associated with car dependency remains. 


\section{Acknowledgements:}

The author is indebted to colleagues in both academic and practitioner circles for helpful and constructive advice in completing this article.

\section{References}

Advertising Standards Agency. (2008). ASA Adjudication on Manchester Against Road Tolls Advertising Standards Authority. Retrieved January 14, 2013, from http://www.asa.org.uk/Rulings/Adjudications/2008/2/Manchester-Against-RoadTolls/TF_ADJ_43972.aspx

Anable, J., Brand, C., Tran, M. \& Eyre, N. (2012). Modelling Transport Energy Demand: A Socio-technical Approach. Energy Policy, 41, 125-38.

Banister, D. (2005). Unsustainable Transport: City Transport in the New Century. Routledge.

Banister, D., Anderton, K., Bonilla, D., Givoni, M. \& Schwanen, T. (2011). Transportation and the Environment. Annual Review of Environment and Resources, 36(1), 247-70.

BBC. (2008a). Anger over C-Charge Bus Adverts. BBC 29/10/2008. Retrieved from November. 20th 2013 from http://news.bbc.co.uk/1/hi/england/manchester/7696425.stm

BBC. (2008b). Kellogg's Defends C-charge E-mail. BBC 04/10/2008. Retrieved February 4, 2013, from http://news.bbc.co.uk/1/hi/england/manchester/7652397.stm

Binns, S. (2008). Peel Holdings Researches C-Charge Advocates' Wards. Crains Manchester $11 / 03 / 2008$.

Brand, R. (2005). Synchronizing Science and Technology with Human Behaviour. Earthscan/James \& James.

Brand, R. \& Fischer, J. (2012). Overcoming the Technophilia/technophobia Split in Environmental Discourse. Environmental Politics, 22(2), 235-54.

Cahill, M. (2007). Why the U-Turn on Sustainable Transport? Capitalism Nature Socialism, 18(4), 90-103.

Campbell, H. \& Marshall, R. (2002). Utilitarianism's Bad Breath? A Re-Evaluation of the Public Interest Justification for Planning. Planning Theory, 1(2), 163-87.

Clean Air Now. (2007). CAN Responds to M.E.N. "Commuter Survey". Retrieved from http://www.manchesterfoe.org.uk/can/pressr.php?id=8 
Clean Air Now. (2008). Press Release: Tour De TIF - 80 Miles, 10 Town Halls, 1 Day - Lots of Cyclists. Retrieved $20^{\text {th }}$ November 2013 from http://www.manchesterfoe.org.uk/can/pressr.php?id=26

DeLyser, D. (2001). "Do You Really Live Here?" Thoughts on Insider Research. Geographical Review, 91(1-2), 441-53.

Department for Transport. (2013). Local Sustainable Transport Fund Annual Report 2011/12. Department for Transport.

Docherty, I. \& Shaw, J. (2008). Traffic Jam: Ten Years of "Sustainable" Transport in the UK. Policy Press.

Docherty, I. \& Shaw, J. (2012). The Governance of Transport Policy, in: Geels, F., Kemp, R., \& Lyons, G. (Eds.), Automobility in transition?: A socio-technical analysis of sustainable transport (pp. 104-22). Routledge.

Dryzek, J. S. (1997). The Politics of the Earth: Environmental Discourses. Oxford University Press.

Dudley, G. \& Chatterjee, K. (2012). The Dynamics of Regime Strength and Instability: Policy Challenges to the Dominance of the Private Car in the United Kingdom, in: Geels, $\mathrm{F}$., Kemp, R., \& Lyons, G. (Eds.), Automobility in transition?: A socio-technical analysis of sustainable transport (pp. 83-103). Routledge.

European Union. (2011). Roadmap to a Single European Transport Area - Towards a Competitive and Resource Efficient Transport System. European Union.

Ferreira, A., Beukers, E. \& Brömmelstroet, M. T. (2012). Accessibility Is Gold, Mobility Is Not: a Proposal for the Improvement of Dutch Transport-related Cost-benefit Analysis. Environment and Planning B: Planning and Design 39(4), 683-97.

Forster, A. (2008). They've Made Their Cases, Now It's up to the Public to Decide. Local Transport Today, (508), 3.

Frank, L. D., Greenwald, M. J., Winkelman, S., Chapman, J. \& Kavage, S. (2010). Carbonless Footprints: Promoting Health and Climate Stabilization Through Active Transportation. Preventive Medicine, 50, S99-S105.

Geels, F., Dudley, G. \& Kemp, R. (2012). Findings, Conclusions and Assessments of Sustainability Transitions in Automobility, in: Geels, F., Kemp, R., Dudley, G., \& Lyons, G. (Eds.), Automobility in transition?: A socio-technical analysis of sustainable transport (pp. 336-73). Routledge.

Geels, F. W. (2012). A Socio-technical Analysis of Low-carbon Transitions: Introducing the Multi-level Perspective into Transport Studies. Journal of Transport Geography, 24, 471-82.

Gill, S. E., Handley, J. F., Ennos, A. R. \& Pauleit, S. (2007). Adapting Cities for Climate Change: The Role of the Green Infrastructure. Built environment, 33(1), 115-33. 
Givoni, M. (2012). Re-assessing the Results of the London Congestion Charging Scheme. Urban Studies, 49(5), 1089-1105.

GMWDA. (2009). GMWDA Our Aim Is Zero Waste. GMWDA Newsletter.

Greater Manchester Future Transport. (2008). Greater Manchester's Future Transport: Why the Transport Innovation Fund? An Analysis of the Rationale Behind the Greater Manchester TIF Package.

Hay, P. R. (2002). A Companion to Environmental Thought. Edinburgh University Press.

Hayman, A. (2010). Councils Throw City-region into Doubt. Regeneration and Renewal. 2010/03/08

Hull, A. (2008). Policy Integration: What Will It Take to Achieve More Sustainable Transport Solutions in Cities? Transport Policy, 15(2), 94-103.

Jackson, T. (2005). Motivating Sustainable Consumption: a Review of Evidence on Consumer Behaviour and Behavioural Change. Energy Environment, 15 (January).

Kemp, R., Geels, W. F. \& Dudley, G. (2012). Introduction: Sustainability Transitions in the Automobility Regime and the Need for a New Perspective, in: Geels, F., Kemp, R., Dudley, G., \& Lyons, G. (Eds.), Automobility in Transition: A Socio-Technical Analysis of Sustainable Transport, (pp. 1-28). Routledge.

King, D., Manville, M. \& Shoup, D. (2007). The Political Calculus of Congestion Pricing. Transport Policy, 14(2), 111-23.

Kirby, D. (2007). Pay to Drive "a Berlin Wall Around the City". Manchester Evening News 25/06/2007, 17.

Kirby, D. \& Welsh, P. (2011). Return Ticket: Congestion Charge Mastermind Roger Jones Set to Return to Transport Committee. Manchester Evening News 02/06/2011. Retrieved January 6, 2012, from http://menmedia.co.uk/manchestereveningnews/news/s/1422501_return-ticketcongestion-charge-mastermind-roger-jones-set-to-return-to-transport-committee

Local Transport Today. (2008). Greater Manchester's TIF Referendum: How Will the People Vote? Local Transport Today (508), 1-11.

Lucas, K. (2004). Running on Empty: Transport, Social Exclusion and Environmental Justice. Policy Press.

Lucas, K. (2006). Providing Transport for Social Inclusion Within a Framework for Environmental Justice in the UK. Transportation Research Part A: Policy and Practice, 40(10), 801-9.

M.E.N. (2007a). Congestion Charging: It's Coming Our Way. Manchester Evening News 24/01/2007. 
M.E.N. (2007b). Bury Blow for Congestion Charge Plans. Manchester Evening News 13/12/2007. Retrieved November $20^{\text {th }}, 2013$ from

http://www.manchestereveningnews.co.uk/news/s/1028222_bury_blow_for_congestion_charge _plans

M.E.N. (2007c). Congestion Charging, You Say NO. Manchester Evening News 21/03/2007.

M.E.N. (2007d). Billboard Campaign over Car Toll Tax. Manchester Evening News 07/07/2007, 6.

M.E.N. (2008). Trafford Centre "Wants Pay-to-drive Leader Out". Manchester Evening News 11/03/2008.

Martens, K., Golub, A. \& Robinson, G. (2012). A Justice-theoretic Approach to the Distribution of Transportation Benefits: Implications for Transportation Planning Practice in the United States. Transportation Research Part A: Policy and Practice, 46(4), 684-95.

Meyer, M. D. (1999). Demand Management as an Element of Transportation Policy: Using Carrots and Sticks to Influence Travel Behavior. Transportation Research Part A: Policy and Practice, 33(7), 575-99.

Millward, D. (2013). Professors Back Pay as You Drive Charging. Daily Telegraph 22/01/2013. Retrieved January 30, 2013 from http://www.telegraph.co.uk/motoring/news/9816282/Professors-back-pay-as-you-drivecharging.html\#\%27

Monbiot, G. (2007). Heat: How to Stop the Planet From Burning. South End Press.

Newman, P. \& Kenworthy, J. (2000). The Ten Myths of Automobile Dependence. World Transport Policy \& Practice, 6(1), 15-25.

Ottewell, D. (2007a). C-Charge: Majority Voting. Manchester Evening News

20/11/2007.Ottewell, D. (2007b). C-charge Gets Public Approval. Manchester Evening News 20/07/2007. Retrieved January 6, 2012 from http://menmedia.co.uk/manchestereveningnews/news/s/1011/1011749_ccharge_gets_ public_approval.html

Ottewell, D. (2008a). C-Charge: A Resounding "NO". Manchester Evening News 12/12/2008. Retrieved $20^{\text {th }}$ November 2013 from http://www.manchestereveningnews.co.uk/news/s/1085031_ccharge_a_resounding_no

Ottewell, D. (2008b). Fergie Backs C-charge. Manchester Evening News 01/12/2008. Retrieved November $20^{\text {th }}, 2013$ from

http://menmedia.co.uk/manchestereveningnews/news/s/1082710_fergie_backs_ccharge

Ottewell, D. (2008c). Stick to Facts Plea on C-charge. Manchester Evening News 25/11/2008. Retrieved December 21 2012, from http://menmedia.co.uk/manchestereveningnews/news/s/1081613_stick_to_facts_plea_on_cchar ge 
Ottewell, D. (2008d). Transport Boss Loses Seat. Manchester Evening News 05/02/2008. Retrieved January 6, 2012 from http://menmedia.co.uk/manchestereveningnews/news/s/1048036_transport_boss_loses _seat

Ottewell, D. (2010). C-charge: You Could Still Have Say. Manchester Evening News 18/04/2010. Retrieved January 6, 2012, from http://menmedia.co.uk/manchestereveningnews/news/s/1053198_ccharge_you_could_ still_have_say

Pierson, P. (2000). Increasing Returns, Path Dependence, and the Study of Politics. American political science review, 94(2), 251-67.

Preston, J. \& Rajé, F. (2007). Accessibility, Mobility and Transport-related Social Exclusion. Journal of Transport Geography, 15(3), 151-60.

Rayner, A. (2011). The End of Motoring. The Guardian. Retrieved January 11, 2013, from http://www.guardian.co.uk/politics/2011/sep/25/end-of-motoring

Rosen, P. (2001). Towards Sustainable and Democratic Urban Transport: Constructivism, Planning and Policy. Technology Analysis \& Strategic Management, 13(1), 117-35.

Royal Institute of Technology, Technical University of Denmark, Swedish National road and Transport Research Unit, Institute of Transport Economics \& Transport Studies Unit. (2011). How to Manage Barriers to Formation and Implementation of Policy Packages in Transport. Royal Institute of Technology.

Rye, T., Gaunt, M. \& Ison, S. (2008). Edinburgh's Congestion Charging Plans: An Analysis of Reasons for Non-implementation. Transportation Planning and Technology, 31(6), 64161.

Ryley, T. \& Gjersoe, N. (2006). Newspaper Response to the Edinburgh Congestion Charging Proposals. Transport Policy, 13(1), 66-73.

Santos, G., Behrendt, H. \& Teytelboym, A. (2010). Part II: Policy Instruments for Sustainable Road Transport. Research in Transportation Economics, 28(1), 46-91.

Schiller, P. L., Bruun, E. C. \& Kenworthy, J. R. (2010). An Introduction to Sustainable Transportation: Policy, Planning and Implementation. Earthscan/James \& James.

Schwanen, T., Banister, D. \& Anable, J. (2012). Rethinking Habits and Their Role in Behaviour Change: The Case of Low-carbon Mobility. Journal of Transport Geography, 24, 52232. 
Sheller, M. (2004). Automotive Emotions Feeling the Car. Theory, Culture \& Society, 21(4-5), 221-42.

Shove, E. \& Walker, G. (2010). Governing Transitions in the Sustainability of Everyday Life. Research Policy, 39(4), 471-6.

Skinner, D. \& Rosen, P. (2007). Hell Is Other Cyclists: Rethinking Transport and Identity, in Horton, D., Rosen, P., \& Cox, P., Cycling and Society, (pp. 83-96). Ashgate.

Sloman, L. (2006). Car Sick: Solutions for Our Car-addicted Culture. Chelsea Green Publishing Company.

Sloman, L., Cavill, N., Muller, L. \& Kennedy, A. (2009). Analysis and Synthesis of Evidence of the Effects of Investment in Six Cycling Demonstration Towns. Department for Transport and Cycling England.

Sorensen, C. H. \& Gudmundsson, H. (2010). The Impact of Governance Modes on Sustainable Transport-the Case of Bus Transport in Greater Manchester, UK. World Review of Intermodal Transportation Research, 3(1), 8-25.

Stockport Express. (2008). Congestion Charge Drives Hard Bargain for Stockport. Stockport Express 11/06/2008. Retrieved September $12^{\text {th }}, 2008$ from http://www.stockportexpress.co.uk/news/s/1053462_congestion_charge_drives_hard_b argain_for_stockport

Sustainable Development Commission. (2011). Fairness in a Car Dependent Society. London: Sustainable Development Commission.

Swanson, J. (2009a). Policy Brief. Gaining Public Support for Congestion Charging: Lessons from Europe for U.S. Metropolitan Areas.

Swanson, J. (2009b). Gaining Public Support for Congestion Charging: Notes from Europe on the Implementation of Bold Transportation Policies.

The Advertiser. (2007). Congestion Charge: Good of Bad Idea? The Advertiser 14/06/2007.

The Bolton News. (2010). Safeguard to Prevent C-Charge Is Welcomed. The Bolton News 09/12/2010.

Thompson, D. (2007). Toll Tax to Cost £1,000 Per Year. The Advertiser.

Unruh, G. C. (2000). Understanding Carbon Lock-in. Energy policy, 28(12), 817-30.

Vigar, G., Shaw, A. \& Swann, R. (2011). Selling Sustainable Mobility: The Reporting of the Manchester Transport Innovation Fund Bid in UK Media. Transport Policy, 18(2), 46879. 
Warren, M. (2012). When, Where and Why Do We Need Deliberation, Voting, and Other Means of Organizing Democracy? A Problem-Based Approach to Democratic Systems.

Rochester, NY: Social Science Research Network. Retrieved January 29th, 2013, from http://papers.ssrn.com/abstract=2104566

Watson, M. (2012). How Theories of Practice Can Inform Transition to a Decarbonised Transport System. Journal of Transport Geography, 24, 488-96.

Whitmarsh, L. (2012). How Useful Is the Multi-Level Perspective for Transport and Sustainability Research? Journal of Transport Geography, 24, 483-7.

Wolmar, C. (2008). Congestion Hurts the Poorest Families Most. New Statesman, 21. 


\begin{tabular}{|l|l|}
\hline January 2007 & Plans first announced in local media \\
\hline Spring 2007 & Initial consultation and political debates \\
\hline July 2007 & $\begin{array}{l}\text { AGMA's TIF bid submitted to national } \\
\text { Government }\end{array}$ \\
\hline Autumn 2007 and Spring 2008 & Research and stakeholder engagement \\
\hline June 2008 & $\begin{array}{l}\text { AGMA's bid accepted by national } \\
\text { Government }\end{array}$ \\
\hline July 2008 & $\begin{array}{l}\text { Consultation on the proposals begins; } \\
\text { Plans for referendum announced }\end{array}$ \\
\hline October 2008 & End of consultation on the proposals \\
\hline December 2008 & $\begin{array}{l}\text { Referendum (a two-week voting period } \\
\text { between } 28^{\text {th }} \text { November and 11 } \\
\text { December) }\end{array}$ \\
\hline
\end{tabular}

Table 1- Outline timeline of the bid, debates, consultations and referendum. 
Figure 1 - Map of the proposals, from 2007 leaflet produced by the Association of Greater Manchester Authorities (AGMA) and the Greater Manchester Passenger Transport Authority (GMPTA). Shows the inner and outer charging rings and the times the charge would be applicable.

Figure 2 - MART campaign video (screen grabs). Source: MART website, discontinued.

Figure 3 - The squirrel mascot for the yes campaign, with slogan. Source: Clean Air Now.

Figure 4 - Roadside advert by Manchester Against Road Tolls (MART). Photo credit: Anonymous.

Figure 5 - Roadside advert by Manchester Against Road Tolls (MART). Photo credit: Anonymous.

Figure 6 - Leaflet produced by Clean Air Now. Source: Clean Air Now.

Figure 7 - Leaflet produced by Clean Air Now. Source: Clean Air Now.

Figure 8 - YES Campaign Adverts. Source: Yes Campaign.

Figure 9 - Beer mat produced by Greater Manchester Momentum Group. Scan of original. 


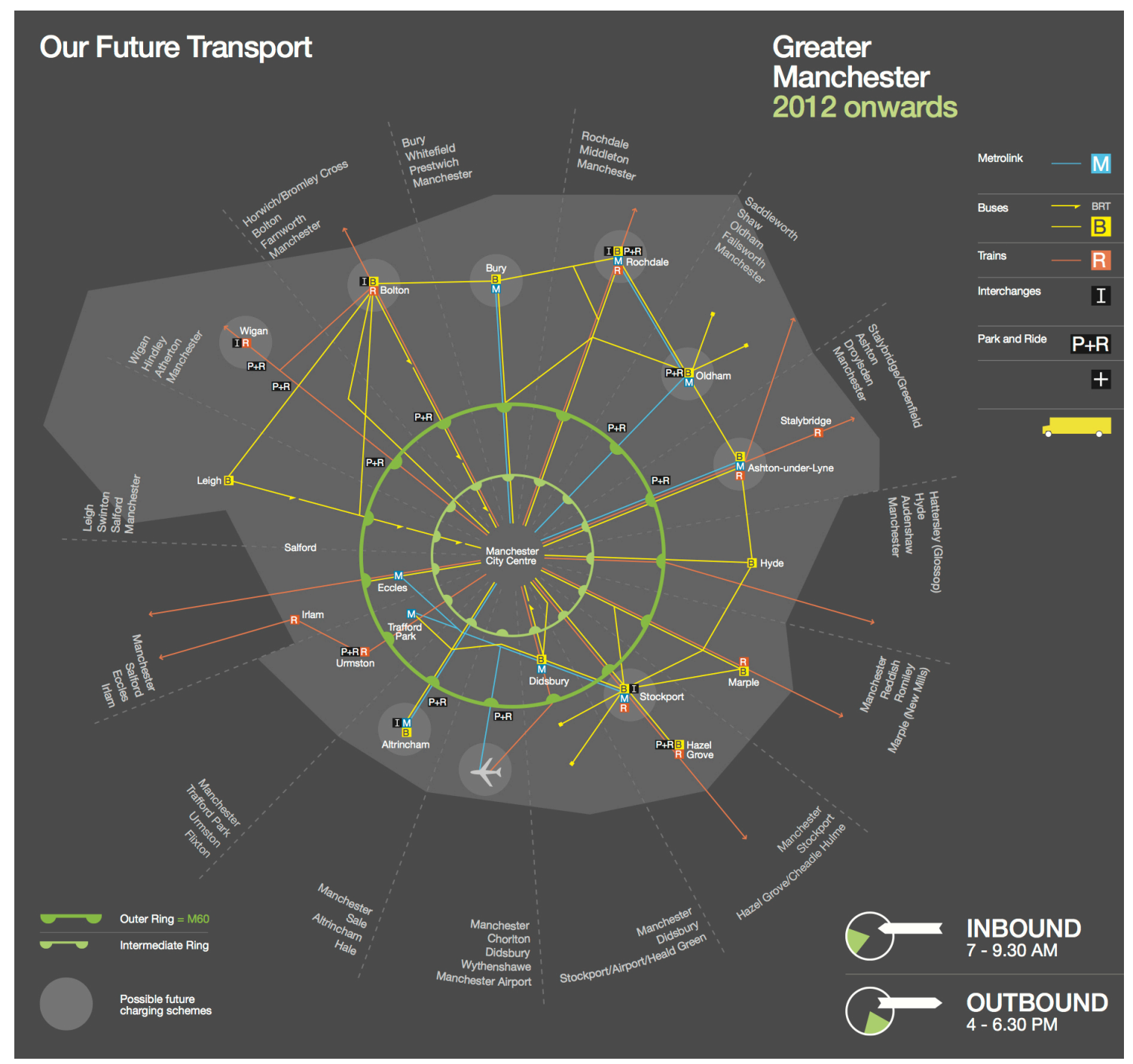

Figure 1 

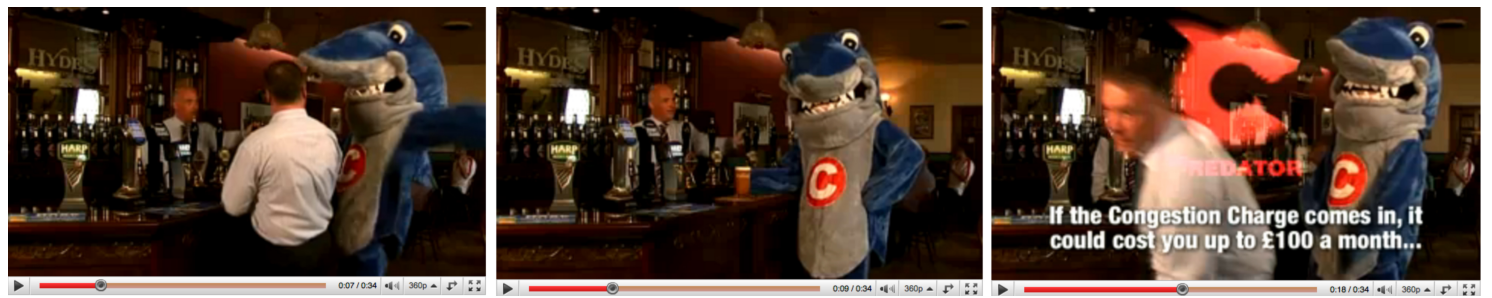

Figure 2

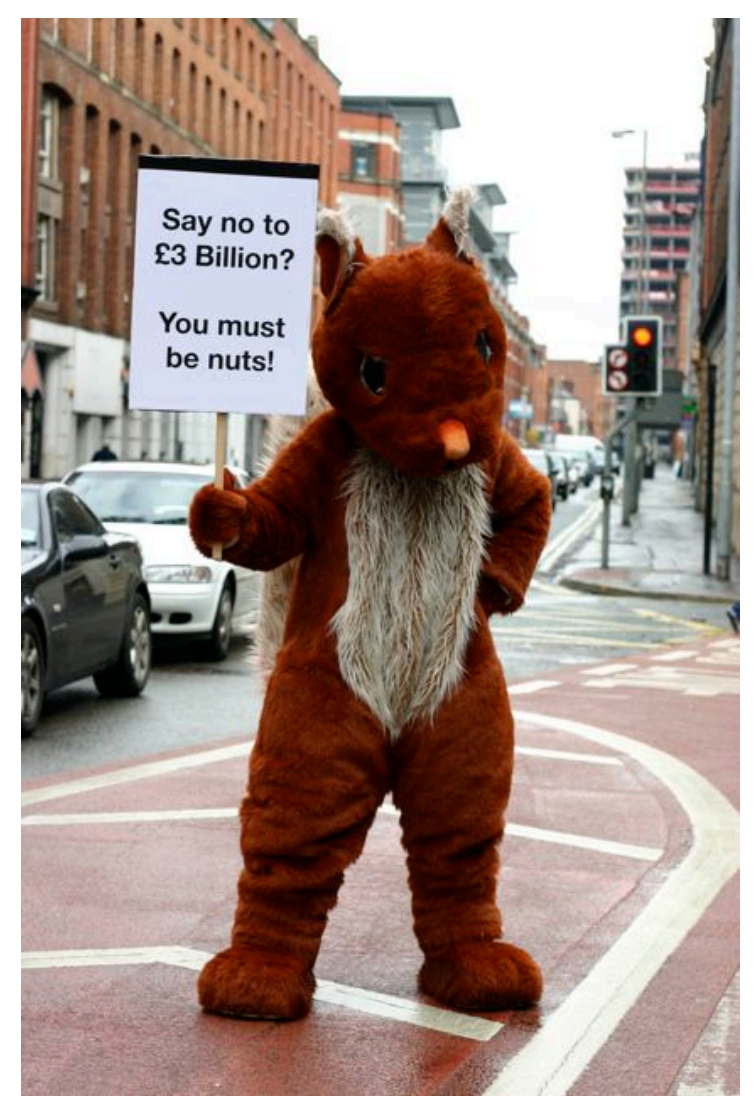

Figure 3 


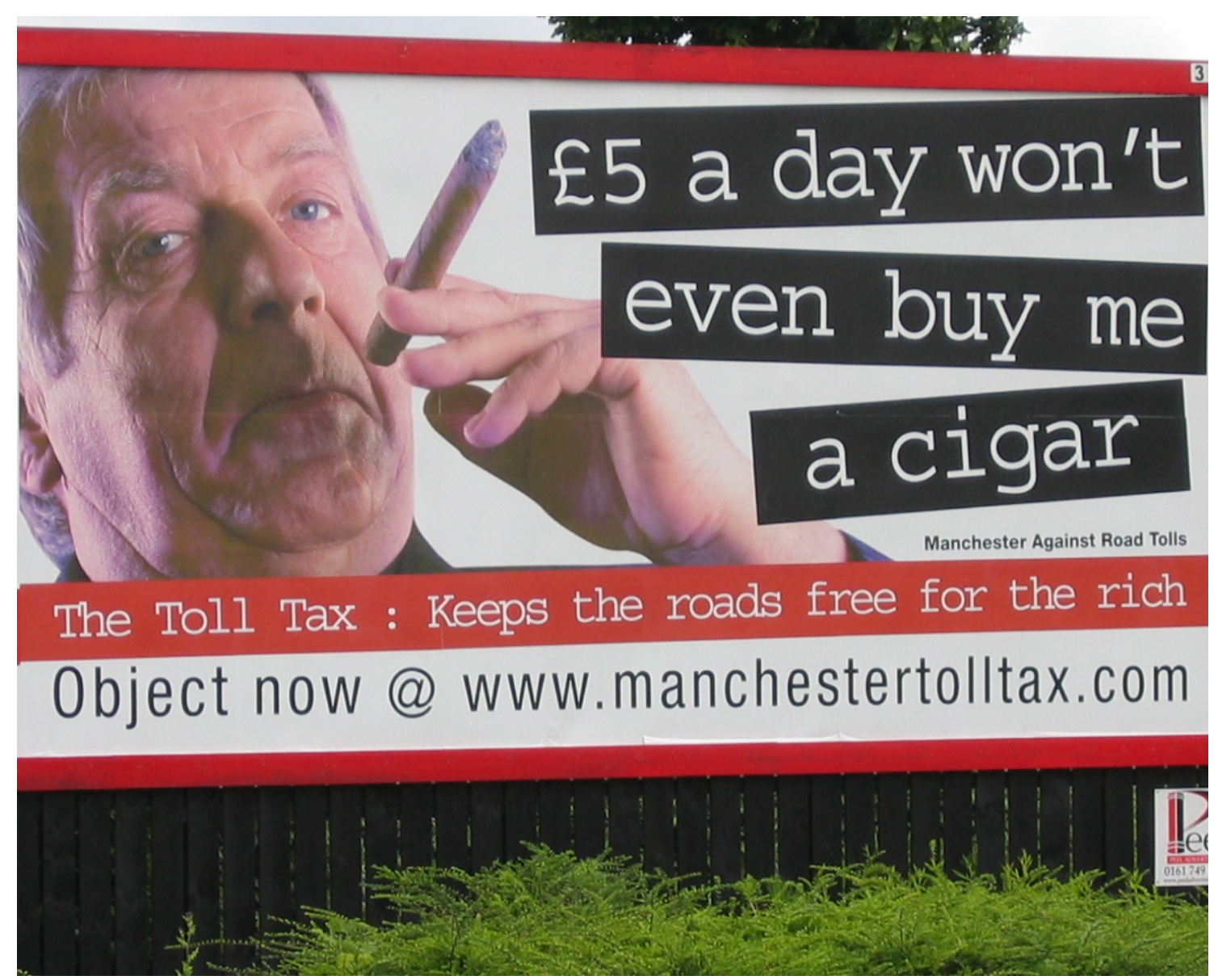

Figure 4

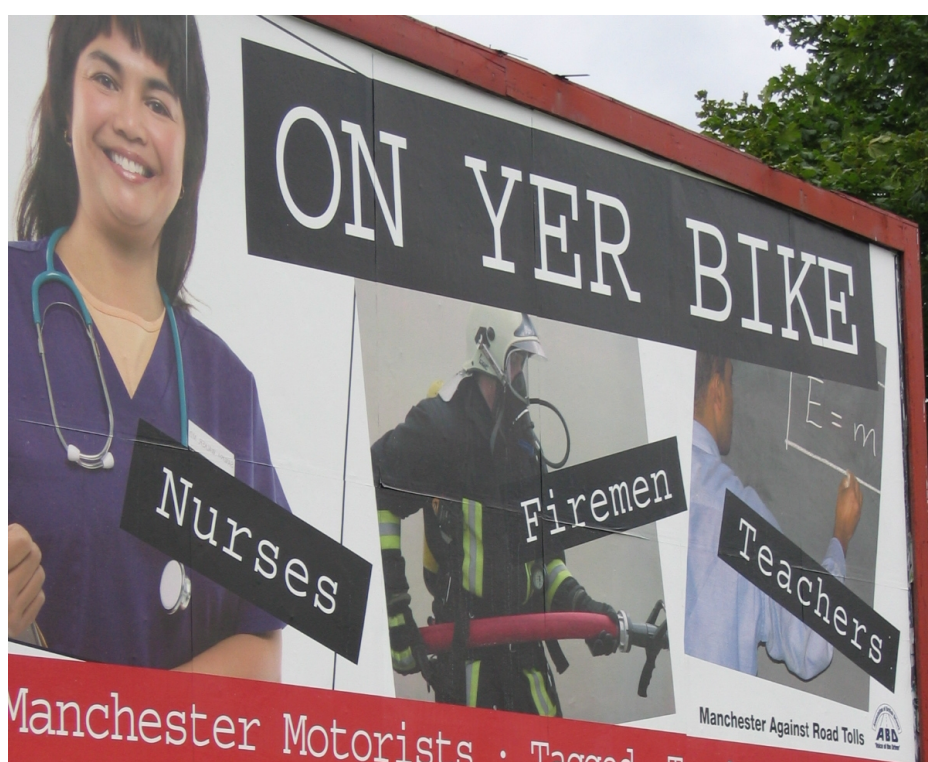

Object now @ www.manchestetertillax.con

Figure 5 
Love Your Bike

Give it an early Christmas

present.

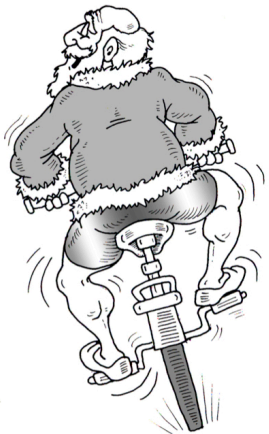

Vote YES in the Transport Innovation Fund Referendum

Figure 6

Typical isn't it?

You wait years for some

transport investment and then

$£ 3$ billion come along at once.

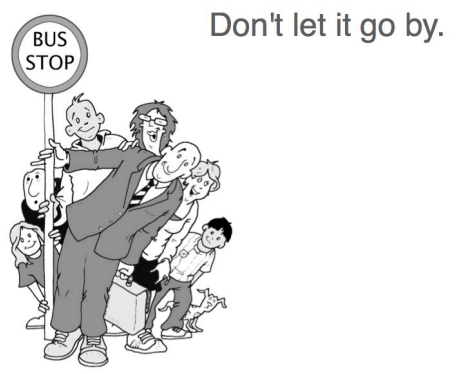

Vote YES in the Transport Innovation Fund Referendum

Figure 7 


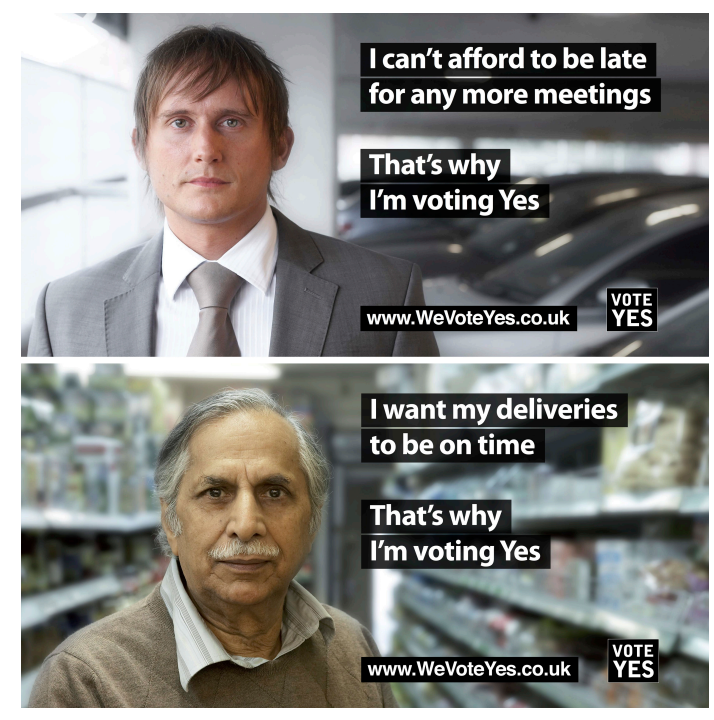

Figure 8

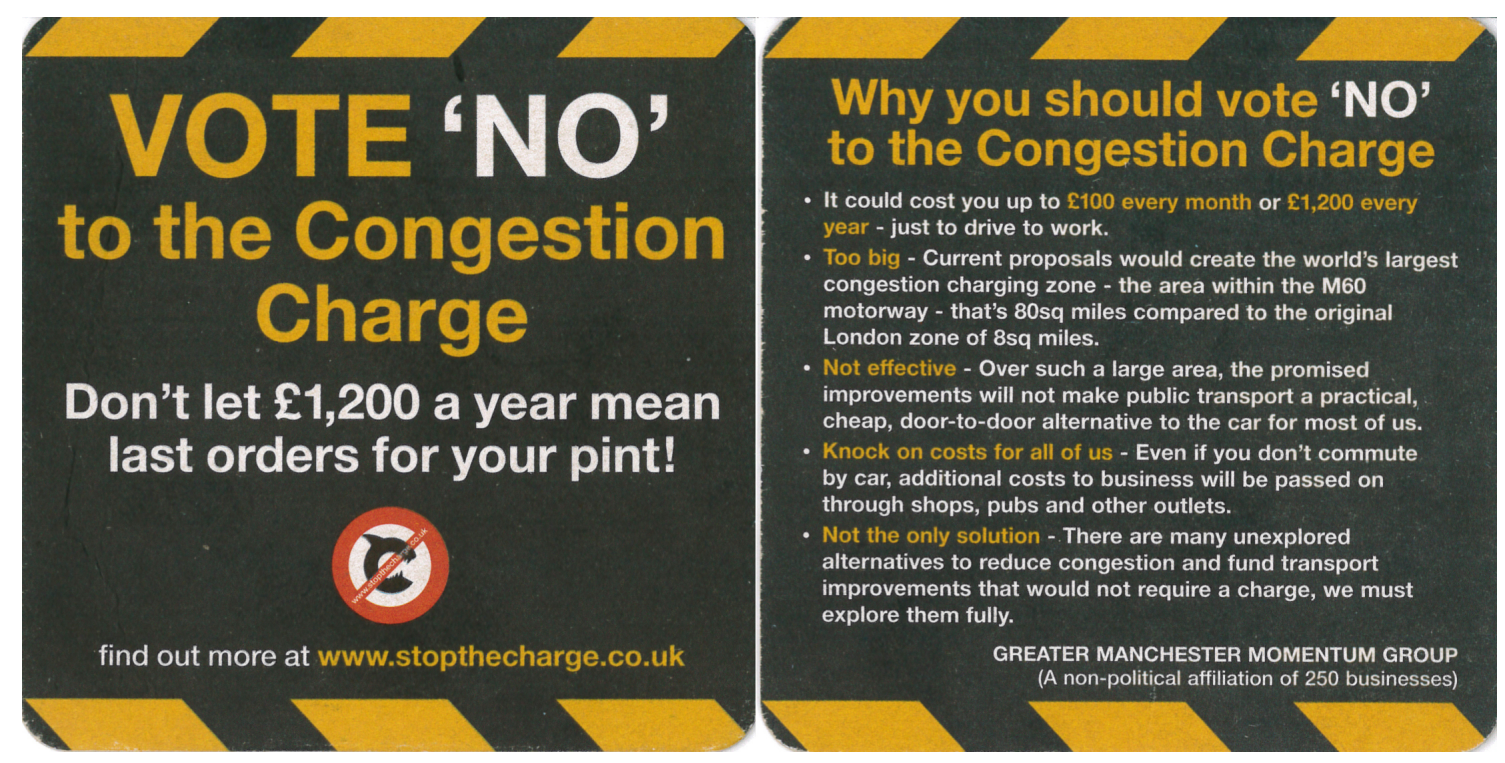

Figure 9 